\title{
Article
}

\section{Finding the Threads in Taiwan History and Historiography}

\author{
Alsford, Niki Joseph paul \\ Available at http://clok.uclan.ac.uk/34458/ \\ Alsford, Niki Joseph paul ORCID: 0000-0003-1939-4313 (2020) Finding the \\ Threads in Taiwan History and Historiography. European Journal of East Asian \\ Studies, 19 . pp. 13-47. ISSN 1568-0584
}

It is advisable to refer to the publisher's version if you intend to cite from the work. http://dx.doi.org/10.1163/15700615-01901007

For more information about UCLan's research in this area go to

http://www.uclan.ac.uk/researchgroups/ and search for < name of research Group>.

For information about Research generally at UCLan please go to http://www.uclan.ac.uk/research/

All outputs in CLoK are protected by Intellectual Property Rights law, including Copyright law. Copyright, IPR and Moral Rights for the works on this site are retained by the individual authors and/or other copyright owners. Terms and conditions for use of this material are defined in the policies page.

\section{CLoK}

Central Lancashire online Knowledge www.clok.uclan.ac.uk

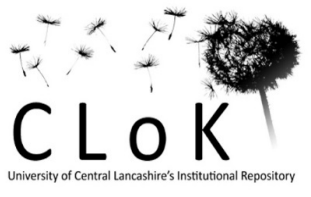


European Journal of

East Asian Studies brill.com/ejea

\title{
Finding the Threads in Taiwan History and Historiography
}

\author{
Niki J.P. Alsford \\ School of Humanities, Language, and Global Studies, University of Central \\ Lancashire, Preston, UK \\ njpalsford@uclan.ac.uk
}

\begin{abstract}
The quest to situate Taiwan, and its history, as a field of study continues to accompany a flow of dirges. Taiwan Studies has been argued to occupy 'a marginal position' within the field of Chinese Studies, while at the same time it is acknowledged that those who are interested in China cannot ignore Taiwan entirely. Some argue that the study of Taiwan is 'an impossible task' since 'Taiwan is already written out of mainstream Western discourse due its insignificance'. This survey (though by no means exhaustive) is an effort to chart the evolution of Taiwan history and historiography and argue that those engaging with the study of Taiwan have always sought ways to adapt and thrive. Attention to this is important as scholars of Taiwan seek to define the field as thing unto itself.
\end{abstract}

\section{Keywords}

Taiwan - historiography - Taiwan Studies - Chinese Studies

In 2015, the School of Oriental and African Studies (sOAS), the University of London hosted the Second World Congress of Taiwan Studies, a congress in which Taiwanologists proposed to (re)define the state of the field for Taiwan Studies. On the second day of the conference the programme consisted of two panels dedicated to the revisiting of the history of Taiwan. The first, Rewriting Taiwan History, had an impressive line-up consisting of Ann Heylen (National Taiwan Normal University), John Shepherd (Virginia), Paul Katz (Institute of Modern History, Academia Sinica) and Rwei-ren Wu (Institute of Taiwan His- 
tory, Academia Sinica). In the afternoon the second panel, Modern Taiwan History, was equally notable with papers presented by Julia Strauss (soAs) and Lung-chih Chang (Institute of Taiwan History). Each of the panellists reflected on past writings and situated their narrative of Taiwan history for the present.

The opening keynote speech for the congress was given by Murray Rubinstein and was in a way similar to the talk he gave in November 2013 when he visited soAs, addressing the crowd of gatherers on the state of the field of Taiwan historiography. In it, he expressed his belief that the writings of Taiwan history can be disseminated into four epochs, each written at critical junctures in Taiwan's past. Taking hold of this thread, this paper will follow it in the hope that it will join with other threads and ultimately lead to a new period initiating changes in the way in which we understand Taiwan's past.

In his paper that accompanied his talk at soAs in 2013, Rubinstein reflects on the evolution of Taiwan Studies as a discipline. As a historian he does this by exploring literature written on Taiwan in what he refers to as four 'transformations of a multi-disciplinary Sub-field,', the first of which, a proto-period, extends from the accounts of the Dutch envoy Wijbrand van Waerwijck, who in 1604 was ordered to create a base on the Pescadores (present-day Penghu) and open trade with China. This 'long, long prelude' threads all the way to 1959. The second period, although not necessarily beginning ex nihilo in 1959, however uses this date as an important marker and starting point with the arrival of the American Fulbright/Foundation Scholarly Exchange researchers who came to see Taiwan as a surrogate for the closed China that they had wished to study. This period ends abruptly in 1978, shortly before the United States shifted diplomatic recognition from the Republic of China (ROC) on Taiwan to the People's Republic of China (PRC) on the mainland. 'International limbo' covers the period from 1979 to 1999 in which "Taiwan as China" is put to death' and the field is changed radically. Rubinstein argues that this was truly a distinctive first period in the study of modern Taiwan. And what is more, Taiwan Studies began to emerge as a kind of Ding an sich in which 'Taiwan in and of itself' was represented as a new 'historical-political-economic socio[-]cultural entity'. The

1 Murray Rubinstein, 'Studying "Taiwan Studies": the evolution and the transformations of a multi-disciplinary sub-field, $1600 \mathrm{CE}$ to $2013 \mathrm{CE}$ ', https://www.soas.ac.uk/taiwanstudies/ events/file89052.pdf, accessed 7 October 2015.

2 Murray Rubinstein, 'The evolution of Taiwan Studies: a personal narrative', keynote speech 
fourth and present period, which this paper calls 'A New Hope', extends from the start of the noughties, when the field evolved within the larger contexts of significant political change in Taiwan with the election of Chen Shui-bian 陳 水扁.

\section{Finding the Threads: The State of the Field for Taiwan} Historiography

I am often asked: Why Taiwan? Why, as a historical anthropologist, have I chosen this island as my focal research point? Why not, is my often trenchant reply. It is, as argued by Shelly Rigger, as if there is a 'widespread expectation ... that anyone who invests the time and effort to learn the language and history of China naturally will choose to study the [PRC]'. ${ }^{3}$ Like Rigger, those of us who have chosen to study Taiwan have often done so because we are better encouraged to 'make comparative links within and beyond the boundaries of East Asia'. Yet to do so, according to Margaret Hillenbrand, has 'several predictable downsides'. Most prominent of these is the scale of conservatism, or 'the degree to which aligning like with like keeps each contrasting object safe within its settled groove rather than making their encounter creatively disruptive. ${ }^{4}$ A rendering to such a problem, Hillenbrand argues, could be achieved by operating Taiwan Studies as a merger. So instead 'of the side-by-side, sealedoff methodologies of comparativism' the studying of Taiwan would achieve greater integration into the disciplines if we were less possessive about it. ${ }^{5}$ In the process of 'letting go' Hillenbrand uses the perspective of Literary Studies as a means to ascribe a different kind of association. Yet, do all disciplines (both within the humanities and social sciences) require such rigid deconstructions? My feelings are: not yet. A simple survey of papers submitted to the European Association of Taiwan Studies (EATS) over the past ten years clearly identify a growing interest in the field. ${ }^{6}$ What is more, the first-year under-

presented at Second World Congress of Taiwan Studies, soAs, the University of London (182o June 2015), 11.

3 Shelly Rigger, 'Political Science and Taiwan's domestic politics: the state of the field', Issues \& Studies 38.4/39.1 (December 2002/March 2003): 50.

4 Margaret Hillenbrand, 'Translationalism and Taiwanese literature', paper presented at the workshop: Discovering Taiwan in Europe, Charles University, Prague (22-23 October 2015), 2.

5 Hillenbrand, 'Translationalism and Taiwanese literature', 3.

6 European Association of Taiwan Studies (EATs), Annual Meeting, http://eats-taiwan.eu/conf erences/, accessed 2 November 2015. I also suspect that if one were to look at the past sub- 
graduate module that I taught for the Approaches to History course at SOAs on Chinese settlers and European encounters with Taiwan indigenous peoples was a popular choice among BA History students, some of whom went on to take the course on Taiwan's Political and Economic Development in their second year as an open option, with one going the extra mile and doing an MA in Taiwan Studies. This is also true for the new course on Taiwan in the Asia Pacific - a second-year module on the BA in Asia Pacific Studies at the University of Central Lancashire that began running from the 2018-2019 academic year. That said, the quest to situate Taiwan as a field of study still continues to accompany a flow of dirges, as the workshop on Discovering Taiwan in Europe in Prague in October 2015 attested. Shelly Rigger herself has argued that Taiwan Studies occupies 'a marginal position' within the field of Chinese Studies, ${ }^{7}$ while at the same time acknowledging that those who are interested in China cannot ignore Taiwan entirely. Shu-mei Shih, on the other hand, sees the study of Taiwan as being 'an impossible task' since 'Taiwan is already written out of mainstream Western discourse due its insignificance. ${ }^{8}$ What is more, she argues that:

'Taiwan' is ... all but illegible to most, since knowing Taiwan does not carry 'value', either symbolic or material, as the significance required for value production is either missing or not recognised. In some sense, the case of Taiwan is similar to that of Hong Kong, which became a significant object of study only when the lightning flash of history accidentally shone upon it. $^{9}$

This pessimistic outlook continued for much of the early noughties. Rubinstein's keynote speech at the Sixth Annual Conference of the European Association of Taiwan Studies (EATS) in Madrid, Spain, in 2009 carried the title: 'Is Taiwan Studies dead?'10 The following restless, edge-of-the-seat Q\&A session, though, was enough to re-energise him into believing that the field, far from

mission of abstracts to the North American Association of Taiwan Studies (NATSA) one would see similar trends. See: NATSA, http://www.na-tsa.org/new/, accessed 2 November 2015.

$7 \quad$ Rigger, 'Political Science and Taiwan's domestic politics', 51.

8 Shu-Mei Shih, 'Globalization and the (in)significance of Taiwan', Postcolonial Studies 6.2 (2003): 144.

9 Shih, 'Globalization', 144.

10 Murray Rubinstein, 'Is Taiwan Studies dead?' paper presented at the EATs annual conference, Madrid (16-18 April 2009). 
being dead, had taken up a whole new life." ${ }^{11}$ One outcome of this 're-immersion' is his co-authored edited volume on Technology Transfer Between the Us, China, and Taiwan. ${ }^{12}$ The title of the conference paper in 2009 , however, prompted Jonathan Sullivan in 2011 to publish an article in the China Quarterly on a similar question on whether Taiwan Studies was in decline. ${ }^{13}$ Sullivan, who is much more sanguine than Shih, argues that rather than lament the 'vigorous growth of China and China studies' those engaging with the study of Taiwan should seek ways to 'adapt to these conditions and thrive.' ${ }^{14}$

Thus, the following survey (though by no means exhaustive) is an effort to similarly chart the evolution of the field of Taiwan Studies and follow the threads of Taiwan historiography through the past. What is more, this paper will chart English-language material (namely in manuscript form) on the history of Taiwan to mark its progression within the field of Taiwan Studies according to the evolutionary table proposed by Rubinstein. In so doing it is hoped that this paper will then identify an emerging fifth period in the writing of Taiwan history and consider whether this also signifies a possible transformative change within the field of Taiwan Studies. ${ }^{15}$ There will naturally be omissions. These are not done on purpose. The examples used are to capture a snapshot of the writing on Taiwan. This is not a complete bibliography, as such is not the intention of this paper. It is duly noted that there is massive scope to develop this by taking into consideration periodicals and more; even, perhaps, the proliferation in more recent years of blogs and websites.

\footnotetext{
11 Rubinstein, 'The evolution of Taiwan Studies', 38-39.

12 Rubinstein, 'The evolution of Taiwan Studies', 4O. See: Murray Rubinstein and Douglas B. Fuller (eds), Technology Transfer Between the Us, China, and Taiwan (Abingdon: Routledge, 2013).

13 Jonathan Sullivan, 'Is Taiwan Studies in decline?' China Quarterly 27 (2011): 706-718.

14 Sullivan, 'Is Taiwan Studies in decline?', 718.

15 In Taiwan one can of course find copious amounts of material written in Chinese on the history of Taiwan that is of seminal quality. This paper, however, will focus primarily on material written in the English language to remain consistent with global Taiwan Studies. One could find extraordinary histories of the island in Japanese, French, German, Dutch, Czech, Italian and so forth, all equally important to the development of Taiwan historiography and arguably the field. Yet it is the purpose of this paper to focus on locating the threads within the overall development of the field.
} 
The European encounter with the island arguably began with the coining of the name, Ilha Formosa, from the Portuguese (then the lingua franca of maritime commerce in Asia) for 'beautiful island' in c. $1580 .{ }^{16}$ Following the establishment of the Dutch entrepôt in 1622 , most writings on the island are naturally in Dutch. The first known English account of the island is perhaps the fabricated account produced by George Psalmanazar in 1705, who claimed to be the first 'Formosan' to visit Europe. In it he discusses in detail the supposed topographical features of the island and the customs and beliefs of its peoples. It was years later that this narrative was proven false and Psalmanazar was labelled an imposter. The man was not born in Taiwan but rather in either Languedoc or Provence in southern France sometime between 1679 and $1684 .{ }^{17}$ Thus the first 'genuine' accounts in English can be found in the archives of the East India Company, and it was commerce that essentially brought the English (and later British) to China. In 1793, following Lord McCartney's embassy to the court of Qianlong, it became clear that trade was to be a one-sided affair. ${ }^{18}$ The British were eager for Chinese ware.

However, attempts were made in the seventeenth century to trade with Zheng Chenggong 鄭成功 (a Ming loyalist who had ousted the Dutch on Taiwan in 1662), when the East India Company sent two vessels to Taiwan. The Bantam and the Pearl arrived in southern Taiwan on 23 June 1670, and three days later East India Company representative Ellis Crisp was given an audience with Zheng Jing 鄭經 (Zheng Chenggong's son). He presented him with a letter from King Charles II seeking permission to be allowed to trade and settle on the island..$^{19}$ On 10 September an accord was agreed and the Company established a factory on the former Dutch site. The Company presence on the island continued until Zheng Keshuang 鄭克塽 surrendered the island to the Qing in 1683. During this short existence on the island no attempts were made to write a history of the island, and as such the material from this period consists exclusively of primary sources. In 1995 Chang Hsiu-jung et al. compiled a collection

16 Shi-shan Henry Tsai, Maritime Taiwan: Historical Encounters with the East and the West (Armonk, NY: M.E. Sharpe, 2009), 5 .

17 George Psalmanazar, A Historical and Geographical Description of Formosa (London:Inner Temple Lane, 1705); also Michael Keevak, The Pretended Asian: George Psalmanazar's Eighteenth-century Formosan Hoax (Detroit, MI: Wayne State University Press, 2004).

18 Michael Greenberg, British Trade and the Opening of China 1800-42 (Cambridge: Cambridge University Press, 1951), 4.

19 IOR: G/21/48. Ellis Crisp at Taiwan to Henry Dacres and Council at Bantam (22 October $1670)$. 
of these archives into an edited volume titled The English Factory in Taiwan, $1670-1685 .{ }^{20}$ Following the closing of the factory, there is little material on the island in English until the 1840s.

Sino-British relations would take on a different flavour following the First Opium War (1839-1842). Details of wartime shipwrecks quickly emerged following the signing of the Treaty of Nanking on 29 August. The Nerbudda, returning from the Chinhai (present-day Zhenhai 鎮海 in Ningbo) campaign, was a troop transport ship. It struck rocks in the northern waters of Taiwan, close to Keelung.

A similar episode occurred on 11 March 1842, when the brig Ann, a former slave-carrying ship that was later converted to an opium-trader, also foundered, on the southwest shore of Tamsui. The narratives of those captured and later executed were written in the form of four diaries known to have existed, and all came from those on board the Ann. Three of these were published in two manuscripts, by Robert Gully and Captain Denham (1844) and Dan Partridge $(1876) .{ }^{21}$ The other diary, written by George Roope, is located in the National Maritime Museum Archives in Greenwich, London. ${ }^{22}$

The period following the Second Opium War (1856-186o) ushered in a greater collection of writings on Taiwan with the opening of four treaty ports. The first of these was opened by Robert Swinhoe in present-day Tainan, with additional ports opening in Tamsui, Keelung and Takao (present-day Kaohsiung). The extraterritoriality of the harbours marshalled in an enclave of foreign residents. At first this consisted mainly of consular staff and agents for trading houses that had been established on the mainland. However, after 1865 the island saw the arrival of the Presbyterian Church of England (PCE) and with it a more settled community keen to document the history and structure of both the Chinese settler society and the Austronesian-speaking indigenous peoples. ${ }^{23}$ Similar to the diaries of the captives as well as the material collected on the seventeenth-century English factory, most of the material written was event-based primary sources and not historiographical-that is, except

20 Chang Hsui-jung, Anthony Farrington, Huang Fu-san, Tsao Yung-ho, Wu Mi-tsa, Cheng His-fu and Ang Ka-im (eds), The English Factory in Taiwan, 1670-1685 (Taipei: National Taiwan University Press, 1995).

21 Robert Gully and Frank Denham, Journals Kept by Mr. Gully and Captain Denham during a Captivity in China in the Year 1842 (London: Chapman and Hall, 1844); and Dan Partridge, British Captives in China: An Account of the Shipwreck on the Island of Formosa of the Brig 'Ann' (London: Wertheimer, Lea, 1876).

22 JOD/233. Journal of George Roope (1842).

23 NikiJ.P. Alsford (ed.), Chronicling Formosa: Setting the Foundations for the Presbyterian Mission, 1865-1876 (Taipei: Shung Ye Museum of Formosan Aborigines, 2015). 
William Campbell's book on Formosa under the Dutch. Published in London by Kegan Paul, Trench, Trubner \& Co. in 1903, it gives an account of the topography of early seventeenth-century Taiwan and the substantive efforts made by the Dutch East India Company (Voc) to proselytise the indigenous communities. In the preface, Campbell makes no attempt to hide its purpose in continuing the evangelising effort of the non-conformist church on the island. ${ }^{24}$ At the back of the book, Campbell makes a systematic bibliography of material written on the island from the Dutch colonial period. Throughout his sojourn, Campbell would go on to write twenty-something articles on Taiwan, namely accounts of his visits to different parts of the island. These were published predominately in the Presbyterian Messenger, a religious magazine published by Hamilton Adams \& Co. on Paternoster Row in the City of London, the 'nucleus of the [then] literary neighbourhood. ${ }^{25}$

Another member of the reformed church (this time from the Canadian Presbytery in northern Taiwan) to write on the island was George Lesley MacKay. Far from Formosa is an attempt to compound a number of themes typical of writings at the time. His narrative starts from his beginnings and his overall perception of the island. ${ }^{26}$ To use Rubinstein, he is a good example of 'missionary orientalism', in particular his description of the island and its peoples. The drive to ethnologically document the island's peoples in such ways was not just a product of the West.

In the winter of 1697 , following a four-day crossing from the mainland, $\mathrm{Yu}$ Yonghe 郁永河 arrived on the island after volunteering for an expedition to Taiwan to obtain sulphur. ${ }^{27} \mathrm{Yu}$ took this opportunity to document the aboriginal communities. The manner in which he wrote clearly alluded to Qing imperialism over the island and, although the first, he was one of a number of similar pioneering travel writers. Others, according to Emma Jinhua Teng, included: Ji Qiguang 季麒光 (one of Taiwan's first county magistrates); Taiwan's first Confucian school instructor, Lin Qianguang 林謙光; the literatus, Xu Huaizu 徐懷祖 (who had travelled in Taiwan for a year); and Wu Zhenchen 吳振臣, a literatus in the entourage of an official who had been assigned to Taiwan. ${ }^{28}$

\footnotetext{
24 William Campbell, Formosa under the Dutch (London: Kegan Paul, Trench, Trubner, 1903), vii-x.

25 John Murray, 'The world of London', Blackwood's Magazine (July 1841): 6o-72.

26 George Lesley MacKay, Far from Formosa (London: Oliphant, Anderson and Ferrier, 1896).

27 Macabe Keliher, Out of China or Yu Yonghe's Tales of Formosa (Taipei: smc Publishing, 2003).

28 Emma Jinhua Teng, Taiwan's Imagined Geography: Chinese Colonial Travel Writing and Pictures, 1683-1895 (Cambridge, MA: Harvard University Press, 2004), 47.
} 
Following the opening of the ports in the nineteenth century and the subsequent push to open the hinterland regions for commercial exploitation (tea, camphor, indigo), scientists and scholars from across the world contributed material towards the documentation of Taiwan indigenous communities. Among them was Albrecht Wirth, who wrote a number of articles, mainly in German with the only known English piece being 'The Aborigines of Formosa and the Liu-Kiu Islands' for American Anthropologist in $1897 .{ }^{29}$ Others include American anthropologist Joseph Beal Steere, whose accounts were carefully compiled by Paul Jen-kuei Li in 2002. ${ }^{30}$ Similar accounts to document the ethnic groups of Taiwan were also attempted by members of the commercial community. The most cited is probably William Pickering's Pioneering in Formosa, published in 1898. ${ }^{31}$ Pickering's zealous writings also provide first-hand accounts of life for many of the foreign community living in the treaty ports. In Shanghai, Robert Bickers has carefully documented a similar account of one resident in Empire Made $\mathrm{Me}^{32}$ Another figure in Taiwan who has generated attention is John Dodd. Dodd, who perhaps is most famous for his diary of the Sino-French War and subsequent yearlong blockade of Taiwan, ${ }^{33}$ also wrote a few papers on the probable origin and customs of the indigenous peoples. ${ }^{34}$ Event-based histories, such as Dodd's account of the Sino-French War, dominate English material published on Taiwan. In 1867 , following the shipwreck of the American merchant ship the Rover and the subsequent killing of its sailors by aborigines in southern Taiwan, the American Consul to Amoy (Xiamen), Charles William Le Gendre, arrived in Taiwan on 18 April to pressure the local authorities to act. Following a number of visits to the island, Le Gendre led a

29 Albrecht Wirth, 'The aborigines of Formosa and the Liu-kiu Islands', American Anthropologist 10.11 (November 1897): 357-370.

30 Paul Jen-kuei Li (ed.), Formosa and its Inhabitants (Taipei: Institute of Taiwan History, Preparatory Office, Academia Sinica, 2002).

31 William Pickering, Pioneering in Formosa (London: Hurst and Blackett, 1898).

32 Robert Bickers, Empire Made Me: An Englishman Adrift in Shanghai (London: Allen Lane, 2003).

33 Niki J.P. Alsford, The Witnessed Account of British Resident John Dodd at Tamsui (Taipei: SMC Publishing, 2010); and John Dodd, Journal of a Blockaded Resident in North Formosa during the Franco-Chinese War, 1884-5 (Hong Kong: Daily Press Office, 1888).

34 John Dodd, 'Formosa', Scottish Geographical Journal 11.11 (1895); John Dodd, 'A few ideas on the probable origin of the hill tribes of Formosa', Journal of the Straits Branch of the Royal Asiatic Society 9 (June 1882): 69-77 and 10 (December 1882): 195-203; John Dodd, 'List of words of Tangão dialect, north Formosa', Journal of the Straits Branch of the Royal Asiatic Society 9 (June 1882): 78-84 and 10 (December 1882): 204-211; and John Dodd, 'A glimpse of the manners and customs of the hill tribes of Formosa', Journal of the Straits Branch of the Royal Asiatic Society 15 (June 1885): 69-78. 
mission, with the aid of William Pickering, to negotiate a treaty with Tauketok (the chief of eighteen Paiwan villages). During the expedition, Le Gendre wrote detailed accounts, which were painstakingly edited by John Shufelt and Douglas Fix in 2012. ${ }^{35}$

At the turn of the century, with Taiwan under Japanese colonial rule since 1895, perhaps the most prolific documenter of Taiwan history is James Wheeler Davidson. In December 1894, acting as an American correspondent for the New York Herald, Davidson was sent to the Far East to report on the Sino-Japanese War (1894-1895). While in Japan, he received a tip-off by the Herald's Far East Bureau Chief, John Cockerill, that further conflict was to befall the island of Taiwan. In March of the following year, he proceeded there as the only foreign journalist, continuing as Us consular agent once Taiwan was part of colonial Japan. Davidson's book The Island of Formosa Past and Present, published by Macmillan, is, according to Rubinstein, 'the largest and most substantive' of the books published during this proto-period. ${ }^{36}$ In spite of a series of inaccuracies, it still continues to be cited.

The Japanese colonial period continued in much the same way as the treaty port era, with a number of books and articles being written. Most of these were still just first-hand accounts and event-based histories. These include, among others, J.D. Clark, Formosa (1896); Campbell Moody, The Saints of Formosa (1912); Marjorie Landsborough, In Beautiful Formosa (1922); and Duncan Macleod, The Island Beautiful (1923). ${ }^{37}$ These books were all written by members of the Presbyterian Mission in Taiwan. ${ }^{38}$ In addition to these accounts, the period also witnessed an increase in travel writing. These include Owen Rutter's Through Formosa: An Account of Japan's Island Colony (1923) and Walton W.H. Murray, Scrambles in Japan and Formosa (1934). ${ }^{39}$ The Japanese accounts,

35 Douglas Fix and John Shufelt (eds), Charles W. Le Gendre: Notes of Travel in Formosa (Tainan: National Museum of Taiwan History, 2012).

36 Rubinstein, 'Studying "Taiwanese Studies", 7.

37 J.D. Clark, Formosa (Shanghai: Shanghai Mercury Office, 1896); Campbell Moody, The Saints of Formosa: Life and Worship in a Chinese Church (Edinburgh: Oliphant, Anderson \& Ferrier, 1912); Marjorie Landsborough, In Beautiful Formosa (London: RTs, 1922); and Duncan Macleod, The Island Beautiful: The Story of Fifty Years in North Formosa (Toronto: Presbyterian Church in Canada, 1923).

38 In 1959, Fr Pablo Fernandez published an account of the role of the Catholic Church on the island during the same period as the Presbyterian mission; see: Fr Pablo Fernandez, One Hundred Years of Dominican Apostolate in Formosa, 1859-1958 (Philippines, 1959; reprinted by sMc Publishing, 1994).

39 Owen Rutter, Through Formosa: An Account of Japan's Island Colony (London: T. Fisher Unwin, 1923); and Walton W.H. Murray, Scrambles in Japan and Formosa (London: Edward Arnold, 1934). 
of which a number were also published in English, include Yosaburo Takekoshi's Japanese Rule in Formosa (1907), which was translated by George Braithwaite in Tokyo. ${ }^{40}$

During the Second World War, Taiwan became the location for a number of Pow camps. During their captivity in the fourteen known prisons, some of those interned there wrote of their experiences. One particular account written by Norman Cliff describes in detail his experience in one of the camps. ${ }^{41}$ Although the book was not published until the 199os, a number of other accounts are held in the Department of Documents in the Imperial War Museum in London. Among the collections are the private papers of a number of prisoners. However, the most substantive work currently being done on this topic is by Michael Hurst and the Taiwan Pow Camps Memorial Society. ${ }^{42}$ The Japanese colonial period undoubtedly contains some of the most well-documented accounts of Taiwan and these two short paragraphs do not necessarily do it justice. It could be argued that this may even constitute a period in and of itself. The author's feelings are, however, that this is just an additional layer of coloniality (although a very different one) that has been in existence since the Dutch. The period is just a bit more detailed and nuanced.

With the surrender of Japan on 15 August 1945, following the signing of the instrument of surrender the Japanese ended their colonial rule over Taiwan and the territory was put under administrative control of the Chinese Nationalists. In spite of this, writings on Taiwan continued unabated, and in much the same way. Edward Band's The History of the English Presbyterian Mission, 18471947 , for example, documents the return of the Mission to Taiwan following its expulsion in $1940 .{ }^{43}$

Having examined this 'long, long prelude' it is now necessary to consider how historiography changed with the arrival of the American Fulbright scholars.

\footnotetext{
$40 \quad$ Yosaburo Takekoshi, Japanese Rule in Formosa (London: Longmans, Green, 1907).

41 Norman Cliff, Captive in Formosa: A British POW's Struggle for Survival, 1942-1945 (Rochford: Rochford Press, 1993).

42 Taiwan Pow Camps Memorial Society, Never Forgotten, http://www.powtaiwan.org/index .php, accessed 20 October 2015 .

43 Edward Band, The History of the English Presbyterian Mission, 1847-1947 (London: Presbyterian Church of England, 1947).
} 
'Educational exchange can turn nations into people, contributing as no other form of communication can to the humanising of international relations': ${ }^{4}$ these words from J. William Fulbright would become the motivation behind the education programme that would send us academics to study abroad. For Taiwan, these academics would arrive not to enhance their understanding of the island itself, but rather to see it as a surrogate for the China that was officially closed to American scholarship following the Nationalist retreat to Taiwan in 1949 .

The early post-war writings on Taiwan in English tended not to be historical. Instead, what was being written was a reflection of the current state of affairs on the island. Most notable of these was George H. Kerr's Formosa Betrayed, published in Boston in 1965. Kerr speaks of his experiences as a United States diplomatic officer in Taiwan who had witnessed first-hand the February 28 Incident (228 Incident, 二二八事件). ${ }^{45}$ Much has since been written on the incident, the legacies of which continue to shape domestic politics within Taiwan today. 46 However, the martial law period that followed, known as the 'White Terror', witnessed a number of books being written by those championing the Taiwan cause who would later live in exile. Chief among them is Peng Min-ming's Taste of Freedom: Memoirs of a Formosan Independence Leader and Wu Zhuliu's The Fig Tree:Memoirs of a Taiwanese Patriot - although this was not translated into English until 2002 (by Duncan Hunter). ${ }^{47}$ Wu's most famous work, though, is arguably The Orphan of Asia, which is considered semi-autobiographical and narrates the experiences of its fictional protagonist, $\mathrm{Hu}$ Taiming. ${ }^{48}$ It was thus within the period after 1959, as argued by Rubinstein, that not only the field of Taiwan Studies but also the writing of Taiwan history began to take on a different direction with the coming of the Fulbright scholars.

44 The Fulbright Program, About Fulbright, Bureau of Educational and Cultural Affairs, http:// eca.state.gov/fulbright/about-fulbright, accessed 4 October 2015

45 George H. Kerr, Formosa Betrayed (Boston, MA: Houghton Mifflin, 1965).

46 Stefan Fleischauer, 'Perspectives on 2/28: the "28 February 1947 uprising” in contemporary Taiwan', in Gunter Schubert and Jens Damm (eds) Taiwanese Identity in the Twentyfirst Century: Domestic, Regional and Global Perspectives (Abingdon: Routledge, 2011), see pp. 36-39 on the development of historical research on the incident. Also, Dafydd Fell, Government and Politics in Taiwan (Abingdon: Routledge, 2012), 12-16.

47 Peng Ming-min, A Taste of Freedom: Memoirs of a Formosan Independence Leader (New York, NY: Holt, Rinehart and Winston, 1972); and Wu Zhuoliu: The Fig Tree: Memoirs of a Taiwanese Patriot, trans. Duncan Hunter (Bloomington, IN: 1st Books Library, 2002).

48 Wu Zhuoliu, Orphan of Asia (New York, NY: Columbia University Press, 2006). 
At the heart of this exchange were predominately anthropologists and not historians by training. Arthur Wolf, who sadly passed away in 2015, arrived in the late 1950s with his wife Margery. Their students, who in their own right would go on to publish extensively on Taiwan (Emily Martin Ahern, Stevan Harrell, Steven Sangren and Robert Weller). ${ }^{49}$ Others included Myron Cohen (as a graduate student at Columbia), David Jordan (then a student at Chicago) and Norma Diamond (then a student at Cornell under the direction of Wolf). Each of them throughout their period of research in Taiwan would later come to recognise a distinctiveness in Taiwan once research on the mainland became more available.

Although highly significant for the field of Taiwan Studies, they had not come to research the depths of its history. Yet in order to create a sense of past in their work, each of them took a historical position from which to start. Arthur Wolf's edited volume on Religion and Ritual in Chinese Society, and in particular his chapter on 'Gods, ghosts, and ancestors', reflected historically how changes in worship were largely a result of the social context which the actors (worshippers) determined. ${ }^{50}$ Marriage and Adoption in China, $1845^{-1945, ~ w h i c h ~ w a s ~ c o-~}$ authored with Chieh-shan Huang and published by Stanford in 1980, is clearly history. ${ }^{51}$ What is more, this is an extremely important manuscript in that it argues from the very beginning that the social practice of marriage and adoption is not homogenous across the Sinophone world, and by examining nine districts in northern Taiwan from 1845 to 1945 the authors successfully showed that 'Chinese marriage and adoption practices were not the simple reflection of uniform ideals. Rather, they were the complex reflections of a variety of forces-demographic, economic, and psychological — that interacted to shape family organization'.52 This concept is critical in the understanding of Taiwan whether as a sub-field of Chinese studies or as a field in its own right. Margery Wolf's Women and the Family in Rural Taiwan too starts with 'some history and some geography' to give her anthropological study historical depth and place. It is here, arguably, that Taiwan within this period received its first historical 'comparison', when Margery Wolf compares Taiwan's early history to that of North America. ${ }^{53}$

\footnotetext{
49 Rubinstein, 'Studying “Taiwanese Studies”', 13.

$5^{\circ}$ Arthur P. Wolf (ed.), Religion and Ritual in Chinese Society (Stanford, cA: Stanford University Press, 1974); his chapter on 'Gods, ghosts, and ancestors' is from pp. 131-183.

$5^{1} \quad$ Arthur P. Wolf and Chieh-shan Huang, Marriage and Adoption in China, 1845-1945 (Stanford, CA: Stanford University Press, 1980).

52 Wolf and Huang, Marriage and Adoption in China, 1.

53 Margery Wolf, Women and the Family in Rural Taiwan (Stanford, cA: Stanford University Press, 1972), 1.
} 
Taiwan's early history is not unlike that of North America. Portuguese explorers 'discovered' the island early in the sixteenth century, and various commercial interests, as well as Japanese and Chinese pirates, laid claim to it for different periods thereafter. The aborigines, a MalayoPolynesian people, were robbed of their land, their dignity, and often their lives by Chinese colonists who followed the explorers. They did not submit with docility; well into the twentieth century there was 'an aborigine problem'. Unwary travellers and forest camphor-workers were prime targets for headhunters, but raids were also conducted against villages on the plains.

Although she is incorrect in some of her assessments, this connection between Taiwan and the colonial history of North America begins a separate narrative from that of the mainland. In so doing, she addresses the importance of the representation of indigenous peoples and their historical struggles, although, that said, the subjects within her study were all contemporaries and of Chinese 華人 descent.

The notion of progress figures quite strongly in writings during this period. Ralph Freedman and John Y. Takeshita's 1969 book Family Planning in Taiwanalthough likewise not history-assesses 'a population problem' in Taiwan and the implementation of family planning in Taichung. ${ }^{54}$ Aside from progress, the concepts of place and space also feature predominately in their writings and this fitted trends in cultural anthropology during the same period. ${ }^{55}$ Bernard Gallin's Hsin Hsing, Taiwan: A Chinese Village in Change is probably the most representative of this. ${ }^{56}$ It was subsequently followed by David K. Jordan, Gods, Ghosts, and Ancestors (1972); Emily Martin Ahern, The Cult of the Dead in a Chinese Village (1973); and Philip Chesley Baily, Religion in a Chinese Town (1975).$^{57}$ The 1970s started to see a shift away from the anthropological publications in

54 Ralph Freedman, and John Y. Takeshita, Family Planning in Taiwan: An Experiment in Social Change (Princeton, NJ: Princeton University Press, 1969).

55 See, for example, Daryl Martin, 'Translating space: the politics of ruins, the remote and peripheral places', International Journal of Urban and Regional Research 38.3 (2014): 11021119 .

56 Bernard Gallin, Hsin Hsing, Taiwan: A Chinese Village in Change (Berkeley, CA: University of California Press, 1966).

57 David K. Jordan, Gods, Ghosts, and Ancestors: The Folk Religion of a Taiwanese Village (Berkeley, CA: University of California Press, 1972); Emily Martin Ahern, The Cult of the Dead in a Chinese Village (Stanford, CA: Stanford University Press, 1973); and Philip Chesley Baily, Religion in a Chinese Town (Taipei: The Orient Cultural Service, 1975). 
which Stanford University Press clearly dominated, beginning, in 1970, with Taiwan: Studies in Chinese Local History. The changes were largely a result of the enormous effort in the later 1950s of the Bank of Taiwan (Taiwan yinhang 臺灣銀行) and the Taiwan Provincial Documents Commission (Taiwan sheng wenxian weiyuanhui 臺灣省文獻委員會) to disclose archives pertaining to Taiwan. The edited volume houses some of the most prominent of historians who worked on Taiwan, among them: Johanna M. Meskill and her social historical study of the Lin family; Harry J. Lamley, who writes on the complexity of the 1895 power shift in Taiwan; Leonard Gordon, who contributes a chapter on the international politics concerning Taiwan; and Edgar B. Wickberg, who writes on late nineteenth-century land tenure in northern Taiwan. ${ }^{58}$

This was followed at the end of the decade by Ralph Crozier's Koxinga and Chinese Nationalism in 1977 and Patricia Tsurumi's exceptional book on Japanese Colonial Education in Taiwan, both published by the East Asian Research Center at Harvard University (now the Fairbank Center for Chinese Studies), which, from its founding in 1955 by John Fairbank, was designed to shift away from the more conventional Sinological studies. ${ }^{59}$ That same year, George Williams Carrington, with the Chinese Material Center in San Francisco, published Foreigners in Formosa $1841-1874{ }^{60}$ In this book Carrington explores the different covets that were expressed by colonial powers. In Harry Lamley's review of the book in 1977 he talks of the 'tragic drama that marked the re-entry of Westerners on the Taiwan scene, foreigners expressed a growing interest in the island'.61 Interestingly, in the year following the publication of both the review and the book, us President Jimmy Carter announced that Washington would cease recognition of Taipei in favour of Beijing - a catalyst that reverberated not only within the Taiwan stock market but also among its other allies, with Taiwan losing an additional seventeen allies over the following ten years. The changes in Taiwan's diplomatic situation would place it

$5^{8}$ Leonard H.D. Gordon (ed.), Taiwan: Studies in Chinese Local History (New York, NY: Columbia University Press, 1970).

59 Ralph C. Crozier, Koxinga and Chinese Nationalism: History, Myth, and the Hero (Cambridge, MA:

East Asian Research Center, Harvard University, distributed by Harvard University Press, 1977); and Patricia E. Tsurumi, Japanese Colonial Education in Taiwan, 1895-1945 (Cambridge, MA: Harvard University Press, 1977).

6o George Williams Carrington, Foreigners in Formosa 1841-1874 (San Francisco, CA: Chinese Materials Center, 1977).

61 Harry J. Lamley, 'Book review: George Williams Carrington, Foreigners in Formosa', Journal of Asian Studies 38.2 (1979): 333-334. 
academically in a kind of international limbo. Yet by 'breaking the China chain' this period would also witness a remarkable degree of writing on Taiwan for Taiwan.

On 29 January 1979, then deputy premier of China, Deng Xiaoping, met Jimmy Carter and collectively signed an accord that not only reversed us opposition to the P RC, but also sealed the fate of the ROC on Taiwan. In so doing, the Us ceased to recognise the government of Chiang Ching-kuo and the appositeness of Taiwan Studies took on a different thread. In response to the 'switch in recognition', opposition forces in Taiwan began to gain momentum. As this year of great change drew to a close these forces clashed. On 10 December 1979, the Formosa Magazine 美麗島雜誌 led by Huang Shin-chieh 黃信介 and other opposition members, the dangwai (also Tangwai 黨外) in commemoration of Human Rights Day staged a demonstration to demand democracy for Taiwan. The government crackdown that ensued would later be referred to as the Kaohsiung Incident 高雄事件. Two months later, in the ensuing purge that followed the incident, Lin Yi-hsiung 林義雄, a leader within the democratic movements, was detained and beaten by police. His wife Fang Su-min 方素敏, after seeing him in prison, contacted Amnesty International's office in Osaka. The following day his mother and twin seven-year-old daughters were murdered in their home. The official line was that they knew nothing despite the house being under 24-hour surveillance. ${ }^{62}$ About the same time, Johanna Menzel Meskill's influential book on a different Lin family took to the shelves. A Chinese Pioneer Family: The Lins of Wu-feng, Taiwan 1729-1895, published by Princeton, charts the pioneering efforts of one man who braved the crossing in 1754. His name was Lin Shih 林石 and he was one of a number of 'obscure men who came to Chang-hua in the mid-eighteenth century'.63 Covering six generations, Meskill maps out the genealogical history of Lin Shih and his descendants. By treating the Lins as a pioneering family, Meskill opens up broad topics that would subsequently shape the manner in which Taiwan is studied-these include immigration (the settlement and the frontier life); identity (kinship ties

\footnotetext{
62 A notable discussion on this is: J. Bruce Jacobs, The Kaohsiung Incident in Taiwan and Memoirs of a Foreign Big Beard (Leiden: Brill, 2016).

63 Johanna Menzel Meskill, A Chinese Pioneer Family: The Lins of Wu-feng, Taiwan 1729-1895 (Princeton, NJ: Princeton University Press, 1979).
} 
and domesticity); domestic politics (strongmen and patterns of violence); and cross-strait relations (links to southeastern coastal regions of China), many of which reverberate in contemporary Taiwan Studies. Meskill thus sets the trend for this period of international limbo by not only focusing on two genealogical branches of this family, but equally launching an evaluation of Taiwan as an independent space in both its absolute and relative forms.

When the Chinese annexed Taiwan in 1683 , they found it a crude and lawless place and such it remained despite all the changes China introduced in the next two centuries. A land of opportunity for countless Chinese settlers, to the officials it proved one of the empire's least governable areas ... Geography and early history provide some clues to Taiwan's restless character. Geographically, Taiwan belongs to a vast chain of islands that stretch along the east coast of Asia from the Kuriles in the north to the Philippines in the south. Near the center of the chain, Taiwan is only some one hundred miles from the China coast, yet marginal to the great subcontinent on which Chinese history unfolded. ${ }^{64}$

It is within these sentences that Taiwan, as a frontier, was now being understood under its own absolute terms. Douglas Mendel's The Politics of Formosan Nationalism published in 1970 is indicative of this. ${ }^{65}$ This trend was followed in 1980 with the publication of China's Island Frontier, a collection of essays edited by Ronald G. Knapp. The contributing authors - consisting of historians, geographers and anthropologists - frame Taiwan's history from the seventeenth century as something unto itself: a noumenon or Ding an sich. The absolute, Taiwan's geographical and climatic features, is covered in part one with papers on the development of land from the pre-Qing periods. Knapp's own paper explores the patterns of settlement and land tenure. The second part frames Taiwan in its relative environment. Titled 'Urbanization and economic integration', the part familiarises readers with the authors that would later make significant contributions to Taiwan historiography. Perhaps most noted of these is Donald R. Deglopper and his enormous contribution to the historical development of Lukang and its trading systems.

Taiwan and its relative landscape (population, land use, settlement patterns, etc.) continued for much of the 8os. Bruce Jacobs's manuscript on local pol-

\footnotetext{
64 Meskill, Chinese Pioneer Family, 56.

65 Douglas Mendel, The Politics of Formosan Nationalism (Berkeley, cA: University of California Press, 1970).
} 
itics in Mazu Township was published 1980. ${ }^{66}$ Two years later, Stevan Harrell and the University of Washington Press published Ploughshare Village: Culture and Context in Taiwan (2015 saw an updated version with a new preface). Like the anthropological studies carried out by the Fulbright scholars in the preceding decades, Harrell gives his study on a village near Sanxia in northern Taiwan a historical context and one with a timeline that would be repeated in subsequent studies on Taiwan history. What, however, marks this particular volume within this period is the localism that it begins to present.

Taiwan was thus only marginally included within world political and economic systems throughout most of the Qing. Ignored by its own nominal government, producing mostly for its own consumption, much of the population was relatively self-sufficient. There are, however, important exceptions to this generalization. There were extensive sugar-producing districts, primarily in the south, and tea districts in the north, whose economy was totally dependent on foreign trade. Ploughshare ... was one of these exceptional communities. ${ }^{67}$

Framing Taiwan as something different, or as sites of singularity, was pursued for much of the decade. Towards the mid-198os attention was drawn to religion and sectarianism. In 1986, David Jordan and Daniel Overmyer published The Flying Phoenix: Aspects of Chinese Sectarianism in Taiwan; Tom Gold's State and Society in the Taiwan Miracle was also published in 1986, with Robert Weller's Unities and Diversities in Chinese Religion and Steven P. Sangren's History and Magical Power in a Chinese Community published the following year. ${ }^{68}$

The year 1987 was also a major turning point in Taiwan with the lifting of martial law. The books that followed tended to reflect these societal changes. Hill Gates's Chinese Working Class Lives: Getting by in Taiwan was published

66 Bruce Jacobs, Local Politics in a Rural Chinese Cultural Setting: A Field Study of Mazu Township, Taiwan (Canberra: Contemporary China Centre, Research School of Pacific Studies, Australian National University, 1980).

67 Stevan Harrell, Ploughshare Village: Culture and Context in Taiwan (Seattle, wA: University of Washington Press, 1982), 19.

68 David K. Jordan and Daniel L. Overmyer, The Flying Phoenix: Aspects of Chinese Sectarianism in Taiwan (Princeton, NJ: Princeton University Press, 1986); Thomas B. Gold, State and Society in the Taiwan Miracle (Armonk, NY: M.E. Sharpe, 1986); Robert P. Weller, Unities and Diversities in Chinese Religion (Washington WA: University of Washington Press, 1987); and Steven P. Sangren, History and Magical Power in a Chinese Community (Stanford, CA: Stanford University Press, 1987). 
that year and Marc Cohen's Taiwanese at the Crossroads the following year. ${ }^{69}$ Both presented a historical context to contemporary society which now is arguably the base of Taiwan historiography, in that it synthesises particular narratives in critical examinations. Politics and policy became the cornerstone for the remaining period. Susan Greenhalgh and Edwin Winker's edited volume Contending Approaches, published in 1988, and John Cooper's A Quiet Revolution were followed by K.T. Li's The Evolution of Policy behind Taiwan's Development Success, framing Taiwan as part of the high-economic growth East Asian Tigers. $^{70}$

The 199os would not only see a tectonic shift in Taiwan's political development but would also usher in a remarkable growth in Taiwan historical writing. All of this arguably started with Rubinstein and his 1991 The Protestant Community of Modern Taiwan, which would help to elevate Taiwan Studies internationally through M.E. Sharpe. ${ }^{71}$ This was followed a year later by James Reardon-Anderson's Pollution, Politics and Foreign Investment in Taiwan, which looks at the 1985 rebellion in Lukang following DuPont's decision to house a titanium dioxide factory in the port town. ${ }^{72}$ The culmination of such efforts would materialise in 1993 with the publication of The Other Taiwan. ${ }^{73}$ What is

69 Hill Gates, Chinese Working Class Lives: Getting by in Taiwan (Ithaca, NY: Cornell University Press, 1987); and Marc J. Cohen, Taiwanese at the Crossroads: Human Rights, Political Development and Social Change on the Beautiful Island (Seattle, wA: Asia Resource Center, University of Washington, 1988).

70 Susan Greenhalgh and Edwin A. Winkler (eds), Contending Approaches to the Political Economy of Taiwan (Armonk, NY: M.E. Sharpe, 1988); John F. Cooper, A Quiet Revolution: Political Development in the Republic of China (Washington, DC: Ethics and Public Policy Center, 1988); and Kuo-ting Li, The Evolution of Policy behind Taiwan's Development Success (New Haven, ст: Yale University Press, 1988). This period also witnessed remarkable growth in doctoral studies on religion in Taiwan. In 199o, for example, at the University of Pennsylvania, Sung Kwang-yu wrote his PhD dissertation on Religion and Society in Qing and Japanese Colonial Taiwan, 1644-1945.

71 Murray A. Rubinstein, The Protestant Community of Modern Taiwan: Mission, Seminary, and Church (Armonk, NY: M.E. Sharpe, 1991). The early 199os also saw the publication of Raymon Myers with Lai Tse-han and Wou Wei, A Tragic Beginning: The Taiwan Uprising of February 28, 1947 (Stanford, CA: Stanford University Press, 1991), which was arguably the first historiographical reflection on the 2-28 Incident in English.

72 James Reardon-Anderson, Pollution, Politics and Foreign Investment in Taiwan: The Lukang Rebellion (Armonk, NY: M.E. Sharpe, 1992). That same year M.E. Sharpe's Taiwan Series also published N.T. Wang's edited volume, Taiwan's Enterprises in Global Perspective (Armonk, NY: M.E. Sharpe, 1992); and Denis Fred Simon and Michael Y.M. Kau (eds), Taiwan: Beyond the Economic Miracle (Armonk, NY: M.E. Sharpe. 1992).

73 Murray A. Rubinstein (ed.), The Other Taiwan: 1945 to the Present. (Armonk, NY: M.E. Sharpe, 1993). 
more, at the other side of the great American continent, Stanford University Press in 1993 published one of the most important pieces of Taiwan historiography with John Shepherd's Statecraft and Political Economy. ${ }^{74}$ This was followed the next year with publication of Mark Allee's seminal piece on Law and Local Society in Late Imperial China, a book which makes enormous use of the important Danxin Dangan 淡新檔案, a series of legal documents handled by the local yamen between 1789 (the earliest in the collection) to $1895 \cdot{ }^{75}$ Although David Buxbaum in 1971 arguably wrote the first account (in English) of the practice of trial law in northern Taiwan, which in turn characterised the archival collections, ${ }^{76}$ it was Mark Allee who used the material in a more social historical survey of northern Taiwan in the nineteenth century.

The field witnessed a good year in 1994, with a number of books being published on Taiwan: Lydia Kung's Factory Women in Taiwan, Rubinstein's The Revival of the Mazu Cult, Stephen O. Murray and Keelung Hong's Taiwanese Culture, Taiwanese Society, Stevan Harrell and Huang Chun-Chieh's edited volume Cultural Change in Postwar Taiwan and Alan Wachman's National Identity and Democratization. ${ }^{77}$ The following year saw the publication of DeGlopper's Lukang. In it DeGlopper addresses a number of historical continuities that exist in the old seaport town, such as the manner in which votes were bought in local elections and the obscure nature of the annual rock fight. ${ }^{78}$ Yet perhaps most remarkable is the use of community — or micro-history — to tackle large questions. This notion of community and change was continued in Robert Marsh's The Great Transformation. ${ }^{79}$

74 John Shepherd, Statecraft and Political Economy on the Qing Frontier, 1600-1800 (Stanford, CA: Stanford University Press, 1993).

75 Mark A. Allee, Law and Local Society in Late Imperial China: Northern Taiwan in the Nineteenth Century (Stanford, CA: Stanford University Press; 1994).

76 David C. Buxbaum, 'Some aspects of civil procedure and practice at the trial level in Tanshui and Hsinchu from 1789-1895', Journal of Asian Studies 30.2 (1971): 255-279.

77 Lydia Kung, Factory Women in Taiwan (New York, NY: Columbia University Press, 1994); Murray A. Rubinstein, The Revival of the Mazu Cult and of Taiwanese Pilgrimage to Fujian (Cambridge, MA: Fairbank Center for East Asian Research at Harvard University, 1994); Stephen O. Murray and Keelung Hong, Taiwanese Culture, Taiwanese Society (Lanham, MD: American University Press, 1994); Stevan Harrell and Huang Chun-Chieh (eds) Cultural Change in Postwar Taiwan (London: Routledge, 1994); and Alan M. Wachman, Taiwan: National Identity and Democratization (New York: M.E. Sharpe, 1994).

78 Donald R. DeGlopper, Lukang: Commerce and Community in a Chinese City (Albany, NY: SUNY Press, 1995).

79 Robert M. Marsh, The Great Transformation: Social Change in Taipei, Taiwan since the 196os (Armonk, NY: M.E. Sharpe. 1996). 
Roughly at the same time as this period an important step towards understanding Taiwan history was made in 1986 with the launch of the Project for Taiwan History Field Research and the subsequent opening of the Taiwan History Field Research Office two years later. In 1993, Prof Huang Fu-san 黃福三, as chairman of an advisory committee, formally established the Preparatory Office for the Institute of Taiwan History. ${ }^{80}$ At the end of the 1990s, Harold Otness, through this office, published an important biographical dictionary of Westerners in Taiwan to $1945 .{ }^{81}$

As both the millennium and this period drew to a close, a remarkable project was initiated, one with which the author has been fortunate to have been involved. The Shung Ye Museum of Formosan Aborigines began a series of books that explore historical writings on Taiwan indigenous peoples as part of their internationalisation efforts. The English material, under the tutelage of Glen Dudbridge at Oxford, was first published in 1999 under the title Aborigines of South Taiwan in the 1880s and this was followed two years later by Henrietta Harrison's Natives of Formosa..$^{82}$ As the sponsorship of publications continued into the noughties, so did an important edited volume: Taiwan: A New History was the book that gave new hope to the field, as both the field as well as historiography began a new thread. ${ }^{83}$

8o On 1 July 2004, the Institute of Taiwan History at Academia Sinica was formally opened under the helm of Chuang Ying-chang 莊英章.

81 Harold M. Otness, One Thousand Westerners in Taiwan, to 1945 (Taipei: ITH, Preparatory Office, 1999).

82 Glen Dudbridge (ed.), Aborigines of South Taiwan in the 1880s (Taipei: Shung Ye Museum of Formosan Aborigines, 1999); and Henrietta Harrison (ed.), Natives of Formosa: British Reports of the Taiwan Indigenous People, 1650-1950 (Taipei: Shung Ye Museum of Formosan Aborigines, 2001). The Shung Ye continues to sponsor a number of archival-based publications. At the same period as the Oxford books, the University of Leiden under the leadership of Leonard Blussé published Dutch archival material with the first volume out in 1999 and the second following a year later. See: Research \& Published, http://www .museum.org.tw/SYMM_en/o5.htm, accessed 1 September 2015.

83 Murray A. Rubinstein (ed.) Taiwan: A New History (Armonk, NY: M.E. Sharpe, 1999). There is more that could perhaps be written on the different sources of funding within Taiwan, such as the Shung Ye Museum, that commission the work on Taiwan. There are a number of different prospective sources in Taiwan, including organisations associated with the country, that could have contributed either directly or indirectly to the publishing work. These include, but are not limited to, the cск Foundation, Taiwan Foundation for Democracy, North America Taiwanese Professors' Association (NAPTA) and the ROC National Science Council. 
The early noughties saw a number of publications, the most prominent of which was on the development of Taiwanese society. With the discipline still dominated by us presses, the University of Hawai'i Press in 2001 published Marc Moskowitz's The Haunted Fetus, then in 2003 Philip Clart and Charles Jones's edited volume Religion in Modern Taiwan, followed a year later by David Jordan et al.'s The Minor Arts of Daily Life. Continuing to dominate the field, in 2005, they published Paul Katz's When the Valleys Turned Blood Red-a historical account of the Tapani Incident in Japanese colonial Taiwan. In 2007 they then published Refracted Modernity: Visual Culture and Identity in Colonial Taiwan, ${ }^{84}$ thus setting the trend for research on the colonial period that subsequently saw Uc Berkeley Press publishing the seminal work Becoming Japanese by Leo Ching. In 2006 Columbia University Press followed with the edited volume Taiwan under Japanese Colonial Rule. ${ }^{85}$ The trend in writing Taiwan history was thus set, and in 2003 this was firmly rooted by Cornell University Press with the publishing of Denny Roy's Taiwan: A Political History. ${ }^{86}$ What followed was a series of books exploring the intricacies of Taiwan history that would essentially define the discipline within the field. Emma Jinhua Teng, Taiwan's Imagined Geography (2004), was followed by Tonio Andrade, How Taiwan Became Chinese (2006), Leonard Gordon, Confrontation over Taiwan (2007), Michael Szonyi, Cold War Island: Quemoy on the Front Line (2008), Borao Mateo, The Spanish Experience in Taiwan (2009), and more recently the publication of micro-histories such as that by Niki Alsford, The Witnessed Account (2010) and Andrade, Lost Colony (2011). ${ }^{87}$ The early noughties also saw the publication by

84 Marc L. Moskowitz, The Haunted Fetus: Abortion, Sexuality, and the Spirit World in Taiwan (Honolulu, HI: University of Hawai'i Press, 2001); Philip Clart and Charles B. Jones (eds), Religion in Modern Taiwan: Tradition and Innovation in a Changing Society (Honolulu, HI: University of Hawai'i Press, 2003); David K. Jordan, Andrew D. Morris and Marc L. Moskowitz (eds), The Minor Arts of Daily Life: Popular Culture in Taiwan (Honolulu, HI: University of Hawai'i Press, 2004); Paul R. Katz, When the Rivers Ran Red with Blood: The Ta-pa-ni Incident in Colonial Taiwan (Honolulu, HI: University of Hawai'i Press, 2005); and Yuko Kikuchi (ed.), Refracted Modernity: Visual Culture and Identity in Colonial Taiwan (Honolulu, Hi: University of Hawai'i Press, 2005).

85 Ping-hui Liao and David Der-Wei Wang (eds), Taiwan under Japanese Colonial Rule, 18951945: History, Culture, Memory (New York, NY: Columbia University Press, 2006).

86 Leo T.S. Ching, Becoming Japanese (Berkeley, CA: University of California Press, 2001); and Denny Roy, Taiwan: A Political History (Ithaca, NY: Cornell University Press, 2003).

87 Emma Jinhua Teng, Taiwan's Imagined Geography: Chinese Colonial Writing and Pictures, 1683-1895 (Cambridge, MA: Harvard University Press, 2004); Tonio Andrade, How Taiwan Became Chinese, Dutch, Spanish, and Han Colonization in the Seventeenth Century (New 
UC Press of Melissa Brown's Is Taiwan Chinese? (2004), which explored ongoing debates surrounding the identity of the peoples of Taiwan that had evolved over the course of its recorded history: a key text within the field. ${ }^{88}$

This surge and the introduction of Taiwan Series in academic presses witnessed momentous developments in writing on Taiwan, the first, under the editorial guidance of Rubinstein, being M.E. Sharpe. The early 2000 saw significant leaps in material with a historical focus. Stéphane Corcuff's edited volume Memoirs of the Future published in 2002 was followed by Richard Bush's At Cross Purposes (2004) and Anru Lee's edited volume on Women in New Taiwan (2007), with Henry Tsai's informative treatise Maritime Taiwan (2008) arriving on the shelves in the latter part of the decade. ${ }^{89}$ However, the most significant development within the field was its growth in Europe.

Established in 1999, the Centre of Taiwan Studies at soAs has arguably become the leading centre for Taiwan Studies globally. The inauguration of the MA in Taiwan Studies programme (the only one outside of Taiwan) provides a programme of interdisciplinary courses on all aspects of Taiwan society. With a firm foundation in Europe, the Centre of Taiwan Studies founded EATs in 2004. In Europe other centres and institutes have followed suit. The European Research Centre on Contemporary Taiwan (E RCCT) in Tübingen, Germany, the Vienna Centre for Taiwan Studies in Austria and the Taiwan Research Centre in Ljubljana, Slovenia, the Taiwan Studies Programme at Nottingham University and the recently launched Northern Institute of Taiwan Studies (NorITS) at the University of Central Lancashire in the UK are a few examples. With this surge in European-based research on Taiwan three established publishing houses have developed a Taiwan Series. In Weisbaden, Germany, Harrassowitz Verlag and Studia Formosiana, under the guidance of Ann Heylen and

York, NY: Columbia University Press, 2006); Leonard H.D. Gordon, Confrontation over Taiwan: Nineteenth-century China and the Powers (Lanham, MD: Rowan \& Littlefield, 2007); Michael Szonyi, Cold War Island: Quemoy on the Front Line (Cambridge: Cambridge University Press, 2008); José Eugenio Borao Mateo, The Spanish Experience in Taiwan, 16261642: The Baroque Ending of a Renaissance Endeavour (Hong Kong: Hong Kong University Press, 20o9); Niki Alsford, The Witnessed Account of British Resident John Dodd at Tamsui (Taipei: SmC Publishing, 2010); and Tonio Andrade, Lost Colony: The Untold Story of China's First Great Victory over the West (Princeton, NJ: Princeton University Press, 2011).

88 Melissa Brown, Is Taiwan Chinese? (Berkeley, CA: University of California Press, 2004).

89 Stéphane Corcuff (ed.), Memories of the Future: National Identity Issues and the Search for a New Taiwan (Armonk, NY: M.E. Sharpe, 2002); Richard C. Bush, At Cross Purposes, Us-Taiwan Relations since 1942 (Armonk, NY: M.E. Sharpe, 2004); Anru Lee and Catherine Farris (eds), Women in the New Taiwan (Armonk, NY: M.E. Sharpe, 2007); and Shih-shan Henry Tsai, Maritime Taiwan (Armonk, NY: M.E. Sharpe, 2008). 
Henning Klöter (other key parents) have, since the early noughties, been publishing mainly on Taiwanese language and culture, with currently eight books: Becoming Taiwan (2010), Japanese Models (2012) and Imaging and Imagining Taiwan (2012) are volumes that examine the complexities of Taiwan through a range of disciplinary backgrounds, but each encased within a historical context. ${ }^{90}$

The other key development, under Dafydd Fell, is the Taiwan Series at Routledge. With currently twenty-six manuscripts, this series is growing. ${ }^{91}$ In terms of history, the only single monograph is Niki Alsford's Transitions to Modernity. This said, a number are historically contextualised. All very indicative of this are Douglas B. Fuller and Murray Rubinstein's edited volume, Technology Transfer between the US, China and Taiwan (2013), Chang Bi-yu's Place, Identity, and National Imagination (2015), Hui-Ching Chang and Richard Holt's Language, Politics and Identity (2015) and Tak-wing Ngo and Hong-zen Wang's Politics of Difference (2011), which has an excellent chapter on Kaohsiung dockworkers by Yi-chi Chen and Tak-wing as well as Ho Ming-sho's chapter on Taiwan's labour movement. ${ }^{92}$ More recently, Brill have also developed a Taiwan Series under the tutelage of Niki Alsford, Mark Harrison and the late Bruce Jacobs.

Europe as a hotbed for Taiwan Studies has not gone unnoticed. The decision to host the Second World Congress of Taiwan Studies in London is an acceptance of this remarkable development. The understanding of the importance of Taiwan within Europe has also seen growth with a number of key historical

90 Ann Heylen and Scott Sommers (eds), Becoming Taiwan: From Colonialism to Democracy (Wiesbaden: Harrassowitz Verlag, 2010); Ann Heylen, Japanese Models, Chinese Culture and the Dilemma of Taiwanese Language Reform (Wiesbaden: Harrassowitz Verlag, 2012); Chang Bi-yu and Henning Klöter (eds), Imaging and Imagining Taiwan: Identity Representation and Cultural Politics (Wiesbaden: Harrassowitz Verlag, 2012).

91 In the discussion of notable Taiwan Series, we should not ignore the recent efforts of Brill, most notably J. Bruce Jacobs's Democratizing Taiwan (2012) and The Kaohsiung Incident (2016); Joel Atkinson's Australia and Taiwan (2012); Chien-Jung Hsu's The Construction of National Identity in Taiwan's Media (2014); and most recently Sophie McIntyre's, Imagining Taiwan: The Role of Art in Taiwan's Quest for Identity (2017).

92 Niki J.P. Alsford, Transitions to Modernity: The Spirit of 1895 and the Cession of Formosa to Japan (Abingdon: Routledge, 2017); Douglas B. Fuller and Murray Rubinstein (eds), Technology Transfer between the Us, China and Taiwan (Abingdon: Routledge, 2013); Chang Bi-yu, Place, Identity, and National Imagination in Post-war Taiwan (Abingdon: Routledge, 2015); Hui-Ching Chang and Richard Holt, Language, Politics and Identity in Taiwan (Abingdon: Routledge, 2015); and T.W. Ngo and Hong-zen Wang (eds), Politics of Difference in Taiwan (Abingdon: Routledge, 2011). The third series is a new development at Brill edited by Bruce Jacobs, Mark Harrison and Niki Alsford. 
texts in Chinese being translated into English, most notably Chou Wan-yao's $A$ New Illustrated History of Taiwan, translated by Carole Plackitt and Tim Casey in 2015, and Xu Ya-xian's Sounds from the Other Side, translated by Jo-hsuan Wang two years earlier. ${ }^{93}$

So what does all this mean? Well, first of all it would seem safe to argue that Rubinstein was right. Taiwan Studies is not dead. Far from it. Instead what is being seen is a geographical shift. Not completely; but by examining published manuscripts on Taiwan it is clear that there is definitely a movement towards the European continent. That said, the role of the North American Association of Taiwan Studies (NATSA) and the work of colleagues in North America continues to influence the scholarship in much the same way as it always has done. If anything, this emergence in Europe in this latter period only gives strength to the argument that Taiwan Studies is not in decline. But what about Taiwan history? It is the author's opinion that there is a growing interest in exploring Taiwan historically, in particular as a bridge between the studies of Chinese and Japanese history. A significant example of this is the work being done by Barak Kushner at Cambridge, Paul Barclay at Lafayette College in the us and Evan N. Dawley with his seminal work Becoming Taiwanese. ${ }^{94}$ All this said, the author agrees that the study of Taiwan, and in particular its history, is marginal. However, the suspension between cultural realities and the struggle to find oneself is perfectly acceptable. The sociology of American Jewry in the 1940s and 5os, championed by Milton Goldberg, used the concept of marginality as method of theory. ${ }^{95}$ Bringing all this together in a search for a new thread on how it links to the concept of 'history-from-below', let's start with this:

I believe that 'history from below' is history which preserves, and which foregrounds, the marginalised stories and experiences of people who, all else being equal, did not get the chance to author their own story. History

93 Chou Wan-yao, A New Illustrated History of Taiwan (Taipei: SMC Publishing, 2015); and Xu Ya-xian, Sounds from the Other Side: The Operatic Interaction between Colonial Taiwan and China during the Early Twentieth Century (Taipei: smc Publishing, 2013).

94 See, for example, Barak Kushner, 'Ghosts of the Japanese Imperial Army: the "White Group” (Baituan) and early post-war Sino-Japanese relations', Past and Present 218.8 (2013): 117-150. For Paul Barclay his recent book Outcasts of Empire:Japan's Rule on Taiwan's 'Savage Border' 1874-1945 (Oakland: University of California Press, 2018) is a good example. And see Evan N. Dawley, Becoming Taiwanese: Ethnogenesis in a Colonial City, 1880s to 1950 s (Cambridge MA: Harvard University Press, 2019).

95 See: Samuel C. Heilman, 'The sociology of American Jewry: the last ten years', Annual Review of Sociology 8.1 (1982): 135-160. 
from below tries to redress that most final, and brutal, of life's inequalities: whether or not you are forgotten. ${ }^{96}$

The work done by the Fulbright anthropologists has given the necessary metadata to produce very rich social history. Ho Ming-sho's Working Class Formation in Taiwan (2014), Scott Simon's Tanners of Taiwan (2005) and Shih Shan Henry Tsai The Peasant Movement and Land Reform in Taiwan, 1924-1951 (2015) have arguably set this trend. ${ }^{97}$ Taiwan associations and institutes need to help nurture this by providing a platform for such research to be rendered. What the discipline needs are histories such as Christian Henriot's Prostitution and Sexuality in Shanghai (2001) and Gail Hershater's Dangerous Pleasures (1997). ${ }^{98}$ In the case of Taiwan, work is being done-but in the form of blog writing-on Wenmeng Building 文萌樓. ${ }^{99}$ A former public brothel in the Datong district of Taipei City, although declared a historic building in 2006, this has only recently been excluded from urban development. Other histories waiting to be written are those on the history of poverty. Vivienne Richmond's Clothing the Poor and Tatsuichi Horikiri's The Stories Clothes Tell provide excellent methodologies for similar research to be done on Taiwan. ${ }^{100}$ Pam Cox and Annabel Hobley's Shopgirls has particular comparatives with the shoppu gāru and depāto gāru in the Kikumoto Department Store in Taipei and the Hayashi Department Store in Tainan during the Japanese period. ${ }^{101}$ Elsewhere on the reconstruction of the

96 David Hitchcock, 'Why history from below matters more than ever', The Many-Headed Monster, https://manyheadedmonster.wordpress.com/2013/o7/22/david-hitchcock-whyhistory-from-below-matters-more-than-ever/, accessed 10 September 2015.

97 Ho Ming-sho, Working Class Formation in Taiwan (London: Palgrave, 2014); Scott Simon, Tanners of Taiwan: Life Strategies and National Culture (Cambridge, MA: Westview Press, 2005); and Shih-Shan Henry Tsai, The Peasant Movement and Land Reform in Taiwan, 19241951 (Portland, ME: Merwin Asia, 2015).

98 Christian Henriot, Prostitution and Sexuality in Shanghai: A Social History 1849-1949 (Cambridge: Cambridge University Press, 2001); and Gail Hershater Dangerous Pleasures: Prostitution and Modernity in Twentieth-century Shanghai (Berkeley, CA: University of California Press, 1997).

99 See: Wenmeng Building, http://www.overthecity.asia/hiddentaiwan/2015/2/16/wenmeng -building-former-brothel-and-area, accessed 25 October 2015.

100 Vivienne Richmond, Clothing the Poor in Nineteenth-Century England (Cambridge: Cambridge University Press, 2013); and Tatsuichi Horikiri, The Stories Clothes Tell: Voices of Working-Class Japan (Lanham, MD: Rowman \& Littlefield, 2016).

101 See: Niki Alsford, The Spirit of 1895: Two Communities, One Petition, and the Cession of Formosa to Japan, (PhD Diss., SOAS, the University of London, 2015); and Pamela Cox and Annabel Hobley, Shopgirls (London: Hutchinson, 2014). A very good journal article on the diaries of one of the shop girls is Hui-yu Caroline Ts'ai, 'Diaries of everyday life in colonial Taiwan', Japan Review 25 (2013): 145-168. 
working day for women is Emily Honig wonderful book on the Shanghai cotton mills. ${ }^{102}$ There is of course much more that could be said. Other topics with similar if not more value (childhood, crime, marriage, health, etc.), so why has there been a reluctance?103 Shonenko:Taiwanese Child Laborers in World War IIJapan, translated by Jonah Chang, is also of course an exception. It most definitely is not a problem with primary sources. ${ }^{104}$ So perhaps the reality is that many feel, as Shih Shu-mei does, that 'the study of a marginal non-Western society such as Taiwan [has] no significant international cultural, economic and political capital.' ${ }^{105}$ The author, however, disagrees. The 'messier and more complex', as Shih refers to the Taiwan situation, provides in my opinion an excellent opportunity to 'get down and dirty' and try to make some sense historically of it all. The marginality that Taiwan offers enables the researcher to focus on the transient nature of its existence. This entity that interconnects across regional and global boundaries, through its marginality enables a complete rejection of the 'total cultural incompatibility between East and West', as agreed on by Sanjay Subrahmanyam (though writing in a different context). ${ }^{106}$ So let's instead seek the edge that Taiwan as a marginal (sub-)field offers us. ${ }^{107}$ The groundwork has been laid by the authors that have navigated the field since its first writings in the seventeenth century. The material is out there.

102 Emily Honig, Sisters and Strangers: Women in the Shanghai Cotton Mills, 1919-1949 (Stanford, CA: Stanford University Press, 1986).

103 Notable exceptions in Chinese are:Xu Shengkai 徐聖凱, Yizhishiqi taibeigaodeng xuexiao yujingyongyangcheng, 日治時期臺北高等學校與菁英養成 [The Establishment of Taihoku High School and the Fostering of Elites during the Japanese Period] (Taipei: National Taiwan University Press, 2012); Chiu-Jhin Chen 陳秋瑾, Xinniang lifu chuantong yu yanbian: taiwan hunli laozhaopianjishi, 新娘禮服傳統與演變 : 臺灣婚禮老照片紀事 [Tradition and Evolution of Bridal Dresses: A Chronical of Old Taiwanese Wedding Photos] (Taipei: Artiste Press, 2013); Wang Yufeng 王御風, Gaoxiong shehui lingdaojieceng de bianqian:yijiuerling-yijiuliuling, 高雄社會領導階層的變遷:1920-1960 [The Changes in Social Leadership of Kaohsiung: 1920-1960] (Kaohsiung: Kaohsiung City Council, 2013); and Wu Wenxing 吳文星, Rishi shiqi taiwan de shehui lingdao jieceng, 日治時期臺灣的社會領 導階層 [Social Leadership during the Japanese Period of Taiwan] (Taipei: Wunan, 2008).

104 Liang-Tse Chang, Pi-Kuei Chen, Jonah Chang and Helen K. Chang (eds), Shonenko: Taiwanese Child Laborers in World War II Japan, Jonah Chang (trans.) (Taipei: Avanguard Publishing, 2001).

105 Shih, 'Globalization', 143.

106 Sanjay Subrahmanyam, 'Connected histories: notes towards a reconfiguration of early modern Eurasia', Modern Asian Studies 31.3 (1997): 735-762.

107 There are several examples, such as 'nationhood identity', 'developmental state' and 'democratisation', where Taiwan has the potential to add to existing larger debates within various academic fields and disciplines. 


\section{References}

Ahern, Emily Martin. The Cult of the Dead in a Chinese Village (Stanford, CA: Stanford University Press, 1973).

Allee, Mark A. Law and Local Society in Late Imperial China: Northern Taiwan in the Nineteenth Century (Stanford, CA: Stanford University Press; 1994).

Alsford, Niki J.P. The Witnessed Account of British Resident John Dodd at Tamsui (Taipei: sMC Publishing, 2010).

Alsford, Niki J.P. Chronicling Formosa: Setting the Foundations for the Presbyterian Mission, 1865-1876 (Taipei: Shung Ye Museum of Formosan Aborigines, 2015).

Alsford, Niki J.P. Transitions to Modernity: The Spirit of 1895 and the Cession of Formosa to Japan (Abingdon: Routledge, 2017).

Andrade, Tonio. How Taiwan Became Chinese: Dutch, Spanish, and Han Colonization in the Seventeenth Century (New York, NY: Columbia University Press 2006).

Andrade, Tonio. Lost Colony: The Untold Story of China's First Great Victory over the West (Princeton, NJ: Princeton University Press, 2011).

Baily, Philip Chesley. Religion in a Chinese Town (Taipei: The Orient Cultural Service, 1975).

Band, Edward. The History of the English Presbyterian Mission, 1847-1947 (London: Presbyterian Church of England, 1947).

Barclay, Paul. Outcasts of Empire: Japan's Rule on Taiwan's 'Savage Border' 1874-1945 (Oakland: University of California Press, 2018).

Bickers, Robert. Empire Made Me: An Englishman Adrift in Shanghai (London: Allen Lane, 2003).

Borao Mateo, José Eugenio. The Spanish Experience in Taiwan, 1626-1642: The Baroque Ending of a Renaissance Endeavour (Hong Kong: Hong Kong University Press, 2009). Brown, Melissa. Is Taiwan Chinese? (Berkeley, CA: University of California Press, 2004). Bush, Richard C. At Cross Purposes, Us-Taiwan Relations since 1942 (Armonk, NY: M.E. Sharpe, 2004).

Buxbaum, David C. 'Some aspects of civil procedure and practice at the trial level in Tanshui and Hsinchu from 1789-1895'. Journal of Asian Studies 30.2 (1971): 255-279. Campbell, William. Formosa under the Dutch (London: Kegan Paul, Trench, Trubner, 1903).

Carrington, George Williams. Foreigners in Formosa 1841-1874 (San Francisco, CA: Chinese Materials Center, 1977).

Chang Bi-yu. Place, Identity, and National Imagination in Post-war Taiwan (Abingdon: Routledge, 2015).

Chang Bi-yu and Henning Klöter (eds). Imaging and Imagining Taiwan: Identity Representation and Cultural Politics (Wiesbaden: Harrassowitz Verlag, 2012).

Chang Hsui-jung, Anthony Farrington, Huang Fu-san, Tsao Yung-ho, Wu Mi-tsa, Cheng 
His-fu and Ang Ka-im (eds). The English Factory in Taiwan, 1670-1685 (Taipei: National Taiwan University Press, 1995).

Chang Hui-Ching and Richard Holt. Language, Politics and Identity in Taiwan (Abingdon: Routledge, 2015).

Chang Liang-Tse, Pi-Kuei Chen, Jonah Chang and Helen K. Chang (eds). Shonenko: Taiwanese Child Laborers in World War II Japan, Jonah Chang (trans.) (Taipei: Avanguard Publishing, 2001).

Chen Chiu-Jhin 陳秋瑾. Xinniang lifu chuantong yu yanbian: taiwan hunli laozhaopianjishi, 新娘禮服傳統與演變： 臺灣婚禮老照片紀事 [Tradition and Evolution of Bridal Dresses: A Chronical of Old Taiwanese Wedding Photos] (Taipei: Artiste Press, 2013).

Ching, Leo T.S. Becoming Japanese (Berkeley, CA: University of California Press, 2001). Chou Wan-yao. A New Illustrated History of Taiwan (Taipei: SMC Publishing, 2015).

Clark, J.D. Formosa (Shanghai: Shanghai Mercury Office, 1896).

Clart, Philip, and Charles B. Jones (eds). Religion in Modern Taiwan: Tradition and Innovation in a Changing Society (Honolulu, HI: University of Hawai'i Press, 2003).

Cliff, Norman. Captive in Formosa: A British Pow's Struggle for Survival, 1942-1945 (Rochford: Rochford Press, 1993).

Cohen, Marc J. Taiwanese at the Crossroads: Human Rights, Political Development (Seattle, wA: Asia Resource Center, 1988).

Cooper,John F. A Quiet Revolution:Political Development in the Republic of China (Washington, DC: Ethics and Public Policy Center, 1988).

Corcuff, Stéphane (ed.) Memories of the Future: National Identity Issues and the Search for a New Taiwan (Armonk, NY: M.E. Sharpe, 2002).

Cox, Pamela, and Annabel Hobley. Shopgirls (London: Hutchinson, 2014).

Crozier, Ralph C. Koxinga and Chinese Nationalism: History, Myth, and the Hero (Cambridge, MA: East Asian Research Center, Harvard University: distributed by Harvard University Press, 1977).

Dawley, Evan N. Becoming Taiwanese: Ethnogenesis in a Colonial City, 1880s to 1950 os (Cambridge MA: Harvard University Press, 2019).

DeGlopper, Donald R. Lukang: Commerce and Community in a Chinese City (Albany, NY: SUNY Press, 1995).

Dodd, John. 'A few ideas on the probable origin of the hill tribes of Formosa'. Journal of the Straits Branch of the Royal Asiatic Society 9 (June 1882): 69-77, and 10 (December 1882): 195-203.

Dodd, John. 'List of words of Tangão dialect, north Formosa'. Journal of the Straits Branch of the Royal Asiatic Society 9 (June 1882): 78-84, and 10 (December 1882): 204-211.

Dodd, John. 'A glimpse of the manners and customs of the hill tribes of Formosa'. Journal of the Straits Branch of the Royal Asiatic Society 15 (June 1885): 69-78. 
Dodd, John. Journal of a Blockaded Resident in North Formosa during the Franco-Chinese War, 1884-5 (Hong Kong: Daily Press Office, 1888).

Dodd, John. 'Formosa'. Scottish Geographical Journal 11.11 (1895).

Dudbridge, Glen (ed.). Aborigines of South Taiwan in the 188os (Taipei: Shung Ye Museum of Formosan Aborigines, 1999).

Fell, Dafydd. Government and Politics in Taiwan (Abingdon: Routledge, 2012).

Fernandez, Fr Pablo. One Hundred Years of Dominican Apostolate in Formosa, 1859-1958 (Philippines, 1959; reprinted by smc Publishing, 1994).

Fix, Douglas, and John Shufelt (eds). Charles W. Le Gendre: Notes of Travel in Formosa (Tainan: National Museum of Taiwan History, 2012).

Fleischauer, Stefan. 'Perspectives on 228: The "28 February 1947 Uprising” in Contemporary Taiwan'. In Taiwanese Identity in the Twenty-first Century:Domestic, Regional and Global Perspectives. Edited by Gunter Schubert and Jens Damm (Abingdon: Routledge, 2011).

Freedman, Ralph, and John Y. Takeshita. Family Planning in Taiwan: An Experiment in Social Change (Princeton, NJ: Princeton University Press, 1969).

Gallin, Bernard. Hsin Hsing, Taiwan: A Chinese Village in Change (Berkeley, CA: University of California Press, 1966).

Gates, Hill. Chinese Working Class Lives: Getting by in Taiwan (Ithaca, NY: Cornell University Press, 1987).

Gold, Thomas B. State and Society in the Taiwan Miracle (Armonk, NY: M.E. Sharpe, 1986).

Gordon, Leonard H.D. (ed.). Taiwan: Studies in Chinese Local History (New York, NY: Columbia University Press, 1970).

Gordon, Leonard H.D. Confrontation over Taiwan: Nineteenth-century China and the Powers (Lanham, MD: Rowan \& Littlefield, 2007).

Greenberg, Michael. British Trade and the Opening of China 1800-42 (Cambridge: Cambridge University Press, 1951).

Greenhalgh, Susan, and Edwin A. Winkler (eds). Contending Approaches to the Political Economy of Taiwan (Armonk, NY: M.E. Sharpe, 1988).

Gully, Robert, and Frank Denham. Journals Kept by Mr. Gully and Captain Denham during a Captivity in China in the Year 1842 (London: Chapman and Hall, 1844).

Harrell, Stevan. Ploughshare Village:Culture and Context in Taiwan (Seattle, wA: University of Washington Press, 1982).

Harrell, Stevan, and Huang Chun-Chieh (eds). Cultural Change in Postwar Taiwan (London: Routledge, 1994).

Harrison, Henrietta (ed.). Natives of Formosa: British Reports of the Taiwan Indigenous People, 1650-1950 (Taipei: Shung Ye Museum of Formosan Aborigines, 2001).

Heilman, Samuel C. 'The sociology of American Jewry: the last ten years'. Annual Review of Sociology 8.1 (1982): 135-160. 
Heylen, Ann. Japanese Models, Chinese Culture and the Dilemma of Taiwanese Language Reform (Wiesbaden: Harrassowitz Verlag, 2012).

Heylen, Ann, and Scott Sommers (eds). Becoming Taiwan: From Colonialism to Democracy (Wiesbaden: Harrassowitz Verlag, 2010).

Hillenbrand, Margaret. 'Translationalism and Taiwanese literature', paper presented at the workshop: Discovering Taiwan in Europe, Charles University, Prague (2223 October, 2015), 2.

Hitchcock, David. 'Why history from below matters more than ever'. The Many-Headed Monster, https://manyheadedmonster.wordpress.com/2013/o7/22/david-hitchcock -why-history-from-below-matters-more-than-ever/, accessed 1o September 2015.

Ho Ming-sho, Working Class Formation in Taiwan (London: Palgrave, 2014).

Honig, Emily. Sisters and Strangers: Women in the Shanghai Cotton Mills, 1919-1949 (Stanford, CA: Stanford University Press, 1986).

IOR: G/21/48. Ellis Crisp at Taiwan to Henry Dacres and Council at Bantam (22 October $1670)$.

Jacobs, J. Bruce. Local Politics in a Rural Chinese Cultural Setting: A Field Study of Mazu Township, Taiwan (Canberra: Contemporary China Centre, Research School of Pacific Studies, Australian National University, 1980).

Jacobs, J. Bruce. The Kaohsiung Incident in Taiwan and Memoirs of a Foreign Big Beard (Leiden: Brill, 2016).

JOD/233. Journal of George Roope (1842).

Jordan, David K. Gods, Ghosts, and Ancestors: The Folk Religion of a Taiwanese Village (Berkeley, CA: University of. California Press, 1972).

Jordan, David K., and Daniel L. Overmyer, The Flying Phoenix: Aspects in Chinese Sectarianism in Taiwan (Princeton, NJ: Princeton University Press, 1986).

Jordan, David K., Andrew D. Morris and Marc L. Moskowitz (eds). The Minor Arts of Daily Life: Popular Culture in Taiwan (Honolulu, HI: University of Hawai'i Press, 2004).

Katz, Paul R. When the Rivers Ran Red with Blood: The Ta-pa-ni Incident in Colonial Taiwan (Honolulu, HI: University of Hawai'i Press, 2005).

Keevak, Michael. The Pretended Asian: George Psalmanazar's Eighteenth-century Formosan Hoax (Detroit, MI: Wayne State University Press, 2004).

Keliher, Macabe. Out of China or Yu Yonghe's Tales of Formosa (Taipei: smc Publishing, 2003).

Kerr, George H. Formosa Betrayed (Boston, MA: Houghton Mifflin, 1965).

Kung, Lydia. Factory Women in Taiwan (New York, NY: Columbia University Press, 1994).

Kushner, Barak. 'Ghosts of the Japanese Imperial Army: the "White Group" (Baituan) and early post-war Sino-Japanese relations'. Past and Present 218.8 (2013): 117-150.

Lamley, Harry J. 'Book review: George Williams Carrington, Foreigners in Formosa'. Journal of Asian Studies 38.2 (1979): 333-334. 
Landsborough, Marjorie. In Beautiful Formosa (London: RTS, 1922).

Lee, Anru, and Catherine Farris (eds). Women in the New Taiwan (Armonk, NY: M.E. Sharpe, 2007).

Li Kuo-ting. The Evolution of Policy behind Taiwan's Development Success (New Haven, ст: Yale University Press, 1988).

Li, Paul Jen-kuei (ed.). Formosa and its Inhabitants (Taipei: Institute of Taiwan History, Preparatory Office, Academia Sinica, 2002).

Liao Ping-hui and David Der-Wei Wang (eds). Taiwan under Japanese Colonial Rule, 1895-1945: History, Culture, Memory (New York, NY:Columbia University Press, 2006).

MacKay, George Lesley. Far from Formosa (London: Oliphant Anderson and Ferrier, 1896).

Macleod, Duncan. The Island Beautiful: The Story of Fifty Years in North Formosa (Toronto: Presbyterian Church in Canada, 1923).

Marsh, Robert M. The Great Transformation: Social Change in Taipei, Taiwan since the 196os (Armonk, NY: M.E. Sharpe. 1996).

Martin, Daryl. 'Translating space: the politics of ruins, the remote and peripheral places'. International Journal of Urban and Regional Research 38.3 (2014): 1102-1119.

Mendel, Douglas. The Politics of Formosan Nationalism (Berkeley CA: University of California Press, 1970).

Meskill, Johanna Menzel. A Chinese Pioneer Family: The Lins of Wu-feng, Taiwan 17291895 (Princeton, NJ: Princeton University Press, 1979).

Moody, Campbell. The Saints of Formosa: Life and Worship in a Chinese Church (Edinburgh: Oliphant, Anderson \& Ferrier, 1912).

Moskowitz, Marc L. The Haunted Fetus: Abortion, Sexuality, and the Spirit World in Taiwan (Honolulu, HI: University of Hawai'i Press, 2001).

Murray, John. 'The world of London'. Blackwood's Magazine (July 1841): 6o-72.

Murray, Stephen O., and Keelung Hong. Taiwanese Culture, Taiwanese Society (Lanham, MD: American University Press, 1994).

Murray, Walton W.H. Scrambles in Japan and Formosa (London: Edward Arnold, 1934).

Myers, Raymon, with Lai Tse-han and Wou Wei. A Tragic Beginning: The Taiwan Uprising of February 28, 1947 (Stanford, CA: Stanford University Press, 1991).

Ngo, T.W., and Hong-zen Wang (eds). Politics of Difference in Taiwan (Abingdon: Routledge, 2011).

Otness, Harold M. One Thousand Westerners in Taiwan, to 1945 (Taipei: IтH, Preparatory Office, 1999).

Partridge, Dan. British Captives in China: An Account of the Shipwreck on the Island of Formosa of the Brig 'Ann' (London: Wertheimer, Lea, 1876).

Peng Ming-min, A Taste of Freedom: Memoirs of a Formosan Independence Leader (New York, NY: Holt, Rinehart and Winston, 1972).

Pickering, William. Pioneering in Formosa (London: Hurst and Blackett, 1898). 
Psalmanazar, George. A Historical and Geographical Description of Formosa (London: Inner Temple Lane, 1705).

Reardon-Anderson, James. Pollution, Politics and Foreign Investment in Taiwan: The Lukang Rebellion (Armonk, NY: M.E. Sharpe, 1992).

Richmond, Vivienne. Clothing the Poor in Nineteenth-century England (Cambridge: Cambridge University Press, 2013).

Rigger, Shelly. 'Political Science and Taiwan's domestic politics: the state of the field'. Issues \& Studies 38.4/39.1 (December 2002/March 2003): 50.

Roy, Denny. Taiwan: A Political History (Ithaca, NY: Cornell University Press, 2003).

Rubinstein, Murray. The Protestant Community on Modern Taiwan: Mission, Seminary, and Church (Armonk, NY: M.E. Sharpe, 1991).

Rubinstein, Murray. The Revival of the Mazu Cult and of Taiwanese Pilgrimage to Fujian (Cambridge, MA: Fairbank Center for East Asian Research at Harvard University, 1994).

Rubinstein, Murray. 'Is Taiwan Studies dead?' Paper presented at the Annual Conference of the European Association of Taiwan Studies (EATS), Madrid (16-18 April, 2009).

Rubinstein, Murray. 'The evolution of Taiwan Studies: a personal narrative'. Keynote speech presented at Second World Congress of Taiwan Studies, soAs, the University of London (18-20 June, 2015), 11.

Rubinstein, Murray, and Douglas B. Fuller (eds.). Technology Transfer Between the Us, China, and Taiwan (Abingdon: Routledge, 2013).

Rutter, Owen. Through Formosa: An Account of Japan's Island Colony (London: T. Fisher Unwin, 1923).

Sangren, Steven P. History and Magical Power in a Chinese Community (Stanford, CA: Stanford University Press, 1987).

Shepherd, John. Statecraft and Political Economy on the Qing Frontier, 1600-1800 (Stanford, CA: Stanford University Press, 1993).

Shih, Shu-Mei. 'Globalization and the (in)significance of Taiwan'. Postcolonial Studies 6.2 (2003): 144.

Simon, Denis Fred, and Michael Y.M. Kau (eds.). Taiwan: Beyond the Economic Miracle (Armonk, NY: M.E. Sharpe. 1992).

Simon, Scott. Tanners of Taiwan: Life Strategies and National Culture (Cambridge, MA: Westview Press, 2005).

Subrahmanyam, Sanjay. 'Connected histories: notes towards a reconfiguration of early modern Eurasia'. Modern Asian Studies 31.3 (1997): 735-762.

Sullivan, Jonathan. 'Is Taiwan Studies in decline?' China Quarterly 27 (2011): 706718.

Szonyi, Michael. Cold War Island: Quemoy on the Front Line (Cambridge: Cambridge University Press, 2008).

EUROPEAN JOURNAL OF EAST ASIAN STUDIES 19 (2020) 1-35 
Taiwan Pow Camps Memorial Society, Never Forgotten, http://www.powtaiwan.org/ index.php, accessed 20 October 2015.

Tatsuichi Horikiri, The Stories Clothes Tell: Voices of Working-class Japan (Lanham, MD: Rowman \& Littlefield, 2016).

Teng, Emma Jinhua. Taiwan's Imagined Geography: Chinese Colonial Travel Writing and Pictures, 1683-1895 (Cambridge, MA: Harvard University Press, 2004), 47.

Ts'ai, Hui-yu Caroline. 'Diaries of everyday life in colonial Taiwan'. Japan Review 25 (2013): 145-168.

Tsai, Shih-shan Henry. Maritime Taiwan (Armonk, NY: M.E. Sharpe, 2008).

Tsai, Shih-shan Henry. The Peasant Movement and Land Reform in Taiwan. 1924-1951 (Portland, ME: Merwin Asia, 2015).

Tsurumi, Patricia E. Japanese Colonial Education in Taiwan, 1895-1945 (Cambridge, MA: Harvard University Press, 1977).

Wachman, Alan M. Taiwan: National Identity and Democratization (New York: M.E. Sharpe, 1994).

Wang, N.T. (ed.). Taiwan's Enterprises in Global Perspective (Armonk, NY: M.E. Sharpe, 1992).

Wang Yufeng 王御風. Gaoxiong shehui lingdao jieceng de bianqian:yijiuerling-yijiuliuling, 高雄社會領導階層的變遷: 1920-1960 [The Changes in Social Leadership of Kaohsiung: 1920-1960]. Kaohsiung: Kaohsiung City Council, 2013)

Weller, Robert P. Unities and Diversities in Chinese Religion (Seattle wA: University of Washington Press, 1987).

Wirth, Albrecht. 'The aborigines of Formosa and the Liu-kiu Islands'. American Anthropologist 10.11 (November 1897): 357-370.

Wolf, Arthur P. (ed.). Religion and Ritual in Chinese Society (Stanford, CA: Stanford University Press, 1974).

Wolf, Arthur P., and Chieh-shan Huang. Marriage and Adoption in China, 1845-1945 (Stanford, CA: Stanford University Press, 1980).

Wolf, Margery. Women and the Family in Rural Taiwan (Stanford, cA:Stanford University Press, 1972).

Wu Wenxing 吳文星. Rishi shiqi taiwan de shehui lingdao jieceng, 日治時期臺灣的社會 領導階層 [Social Leadership during the Japanese Period of Taiwan]. Taipei: Wunan, 2008)

Wu Zhuoliu. The Fig Tree: Memoirs of a Taiwanese Patriot (Bloomington, IN: 1st Books Library, 2002).

Wu Zhuoliu. Orphan of Asia (New York, NY: Columbia University Press, 2006).

Xu Shengkai 徐聖凱. Yizhi shiqi taibei gaodeng xuexiao yu jingyong yangcheng, 日治時 期臺北高等學校與菁英養成 [The Establishment of Taihoku High School and the Fostering of Elites during the Japanese Period] (Taipei: National Taiwan University Press, 2012). 
Xu Ya-xian. Sounds from the Other Side: The Operatic Interaction between Colonial Taiwan and China during the Early Twentieth Century (Taipei: SMC Publishing, 2013). Yosaburo Takekoshi. Japanese Rule in Formosa (London: Longmans, Green, 1907). Yuko Kikuchi (ed.). Refracted Modernity: Visual Culture and Identity in Colonial Taiwan (Honolulu, HI: University of Hawai'i Press, 2005). 